and structures innervated by them. The Pharmacological Basis of Therapeutics. Edited by Goodman, L.S. A:D GILman, A., p. 533-564, MacMillan, Now York (1975)

\title{
REGIONAL AND SPECIES DIFFERENCES IN THE RESPONSE OF ISOLATED ARTERIES TO ANGIOTENSIN II
}

\author{
Noboru TODA and Mizuo MIYAZAKI \\ Department of Pharmacology, Shiga University of Medical Sciences, Seta, \\ Ohtsu 520-2l, Japan
}

Accepted January 23, 1978

Angiotensin II (Ang-II) is a potent vasoconstrictor octapeptide formed in vivo from angiotensinogen by renin and angiotensin I converting enzyme. The contractile response to Ang-II has been studied in a variety of isolated vessels from different species, and sensitivity of vascular smooth muscles to Ang-II is reportedly quite different (reviewed by Bohr, 1). However, the heterogeneity of vascular smooth muscles in the responsiveness to the polypeptide has not been systematically investigated.

In the present work, mongrel dogs, weighing 7 to $15 \mathrm{~kg}$, were anesthetized with sodium pentobarbital and sacrificed by bleeding from carotid arteries. The brain, heart and kidney were isolated. Basilar, middle ccrebral and posterior cerebral arteries were removed from the brain, the distal portion of ventral interventricular branch of left coronary arteries from the heart, and the interlobar branch of renal arteries from the kidney. The distal portion of superior mesenteric, femoral, internal carotid, external carotid and common carotid arteries was isolated. Cerebral arteries were also obtained from humans, cows, puppies, cats and rabbits. The arteries were helically cut into strips, which were vertically fixed between hooks in the bathing media maintained at $37 \pm 0.5^{\circ} \mathrm{C}$. Details of the experimental procedures are described in previous reports $(2,3)$. Isometric contractions were displayed on an ink-writing oscillograph (Sanei Sokki Co., Tokyo).

The addition of Ang-II in concentrations ranging from $10^{-9}$ to $5 \times 10^{-7} \mathrm{M}$ produced a contraction in dog arterial strips, the maximum being attained at $10^{-i} \mathrm{M}$. The contractile response of different arteries from dogs to this concentration of Ang-II markedly differed (Fig. 1). Cerebral arteries, including basilar, middle cerebral and posterior cercbral, and renal arteries responded to Ang-II with only a slight contraction (approx. 10\% the $\mathrm{K}^{+}$induced contraction), internal carotid, common carotid and coronary arteries with a moderate contraction (45 to $60 \%$ ), and mesenteric and femoral arteries with a marked contraction (90 to $100 \%$ ). Only slight contractions in response to $10^{-7} \mathrm{M}$ Ang-II were induced in cerebral arteries from puppies and cows, whereas in these arteries from humans, cats and rabbits, angiotensin-induced contractions were approx. the same as those elicited by $30 \mathrm{mM}$ $\mathrm{K}^{+}$(Fig. 2). Responses to Ang-II of mesenteric, femoral and cerebral arteries were suppressed or abolished by $10^{-9} \mathrm{M} \mathrm{Sar}^{1}{ }^{\text {Ileu}}{ }^{3}$-Ang-II. At this concentration of the antagonist, 


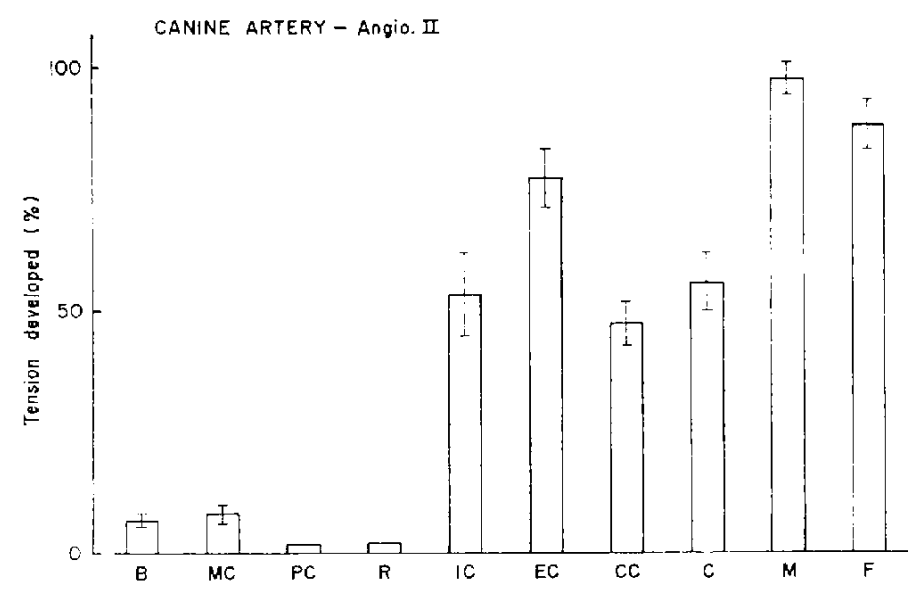

Fig. 1. Contractile responses to $10^{-7} \mathrm{M}$ Ang-II of different arteries from dogs. Contractions induced by $30 \mathrm{mM} \mathrm{K}$ were taken as $100 \%$ : mean values of $\mathrm{K}^{+}$-induced contractions in basilar (B), middle cerebral (MC), posterior cerebral (PC), renal (R), internal carotid (IC), external carotid (EC), common carotid (CC), coronary (C), mesenteric $(\mathrm{M})$ and femoral arteries $(\mathrm{F})$ were $1422 \pm 125 \mathrm{mg}(\mathrm{N}=25), 639 \pm 69$ mg $(\mathrm{N}=17), 500 \pm 74 \mathrm{mg}(\mathrm{N}=10), 1604 \pm 173 \mathrm{mg}(\mathrm{N}=16), 1142 \pm 130 \mathrm{mg}(\mathrm{N}=15)$. $1956 \div 194 \mathrm{mg}(\mathrm{N}=15), 3152 \div 303 \mathrm{mg}(\mathrm{N}=13), 1562 \div 111 \mathrm{mg}(\mathrm{N}=20), 1984 \pm 141$ $\mathrm{mg}(\mathrm{N}=29)$ and 1206$\lrcorner 105 \mathrm{mg}(\mathrm{N}=16)$, respectively. Vertical bars represent standard errors of means.

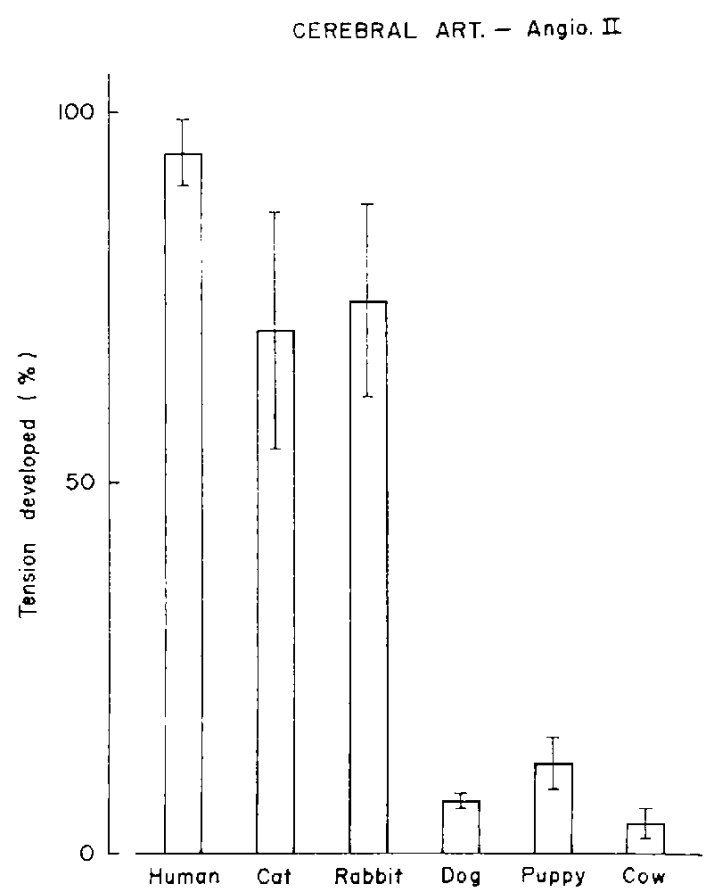

Fig. 2. Contractile responses to $10^{-7} \mathrm{M}$ Ang-II of cerebral arteries from different species. Contractions induced by $30 \mathrm{mM} \mathrm{K}^{+}$were taken as $100 \%$ : mean absolute values in humans, cats, rabbits, dogs, puppies and cows were $2172-281 \mathrm{mg}$ $(\mathrm{N}=18), 732 ! 157 \mathrm{mg}(\mathrm{N}=7), 408 ! 43 \mathrm{mg}(\mathrm{N}=14), 1422 \pm 125 \mathrm{mg}(\mathrm{N}-25)$, $826 \pm 172 \mathrm{mg}(\mathrm{N}=7)$ and $1412 \div 188 \mathrm{mg}(\mathrm{N}=13)$, respectively. 
contractile responses to $\mathrm{K}^{+}(20 \mathrm{mM})$ or serotonin $\left(10^{-9}\right.$ to $\left.2 \times 10^{-6} \mathrm{M}\right)$ were not influenced.

The present study revealed that contractile responses to Ang-II were markedly smaller in dog cerebral and renal arteries than in dog mesenteric and femoral arteries and also in cerebral arteries from humans, cats and rabbits. Relative unresponsiveness of dog renal arteries to the octapeptide has also been reported $(4,5)$. Despite a marked difference in the magnitude of responses of dog mesenteric, femoral and cerebral arteries, these responses were suppressed by Ang-II antagonist in a concentration insufficient to alter the response to $\mathrm{K}^{+}$and serotonin, suggesting that these responses are associated with stimulation of specific Ang-II receptors. Such regional and species differences in the response to Ang-II may be due to different populations or sensitivity of receptive sites which are specifically stimulated by Ang-II and which are responsible for an increase in the influx and mobilization of $\mathrm{Ca}^{++}$. Such differences are probably not due to different sensitivities of processes shared by other agonists, since $\mathrm{K} \div$ and prostaglandin $\mathrm{F}_{2 \alpha}$ induced a similar degree of contraction in cerebral and peripheral arteries from dogs (6). Different susceptibilities to Ang-II of a variety of arteries from different species indicate that the participation of the biogenic octapeptide in the control of regional circulation may be quite different.

Acknowledgements: The authors express their gratitude to Mr. H. Usui for his excellent technical assistance. The study was supported in part by the Takeda Medical Research Foundation.

\section{REFERENCES}

1) Bohr, D.F.: Angiotensin on vascular smooth muscle. Angiotensin, Edited by PAGE, I.H. AND Bumpus, F.M. p. 424-440, Springer-Verlag, Berlin, Heidelberg, New York (1974); 2) TodA, N.: Actions of bradykinin on isolated cerebral and peripheral arteries. Am. J. Physiol. 232, H267H274 (1977); 3) TODA, N., HAYASHI, S. AND HATANO, Y.: Length-tension relationship in isolated canine cerebral arteries. Japan. J. Pharmacol. 26, 129-131 (1976); 4) BOHR, D.F. AND UCHIDA, E.: Individualities of vascular smooth muscles in response to angiotensin. Circulation Res. 20/21 (Suppl. II): II-135-II-145 (1967); 5) SomLYo, A.P. AND SomLYo, A.V.: Electrophysiological correlates of the inequality of maximal vascular smooth muscle contraction elicited by drugs. Proc. Symp. Physiol. Pharmacol., Vascular Neuroeffector System, p.216-221, S. Kager, Basel (1971); 6) HAYASHI, S. AND TODA, N.: Inhibition by $\mathrm{Cd}^{++}$, verapamil and papaverine of $\mathrm{Ca}^{++}$-induced contractions in isolated cerebral and peripheral arteries of the dog. Brit. J. Pharmacol. 60, 35-43 (1977) 